\title{
Sport-Specific Morphology Profile: Differences in Anthropometric Characteristics between Elite Soccer and Basketball Players
}

\author{
Bojan Masanovic ${ }^{1}$, Andjela Vukcevic ${ }^{2}$, Spasoje Spaic ${ }^{1}$ \\ ${ }^{1}$ University of Montenegro, Faculty for Sport and Physical Education, Niksic, Montenegro, ${ }^{2}$ Montenegrin Sports Academy, Podgorica, Montenegro
}

\begin{abstract}
The aim of this study was to obtain relevant knowledge about significant differences in some anthropometric characteristics of top soccer and basketball players. The sample included 39 male subjects divided into two subsamples. The first subsample included 26 subjects, who trained in the senior selection in the Football club Vojvodina from Novi Sad, while the other subsample included 14 subjects who trained in the senior selection in the Basketball club Vojvodina, from Novi Sad. The variables sample included 20 anthropometric measures that defined longitudinal and transversal dimensionality of skeleton, body volume and body mass, and subcutaneous adipose tissue. The results were analysed in a statistical procedure marked as a significance testing of two arithmetic means of the independent samples, a t-test at the level of significance of $p<0.05$. It was concluded, based on these results that significant differences occur in all variables for evaluation of longitudinal and transversal dimensionality of skeleton, as well as for body volume and body mass. When we talk about subcutaneous adipose tissue significant differences occur in all variables except for the skinfold of the upper arm.
\end{abstract}

Key words: Anthropometric Characteristics, Soccer Players, Basketball Player, Professional Sport

\section{Introduction}

Top athletes, who engage in different sports activity, are different in physical and physiological characteristics. It is expected for a top athlete to represent an expression of potential through heritage, training, nutrition, and sociocultural factors (Bourgois et al., 2000). An interdisciplinary approach in any sport discipline is required for the individual's sporting development since it enables task completion during competition or training process (Bjelica, 2002; Bjelica \& Fratrić, 2011; Bjelica, 2013). There are certain specifics and differences in competition structure in every sport, so the need for continuous research and confirmation of these specifics in practice is imposed (Masanovic \& Vukasevic, 2009).

Anthropometry is the method of measuring the human body or individual body parts. Its purpose is to quantify and define morphological traits, and provide us with an objective image of the state of growth of the person tested. Morphological charac- teristics appear to be of great importance for orientation and selection in most sports disciplines. Given that they are present in the specification equation of every sport, morphological characteristics take up one of the major positions. For a large number of sports disciplines, the morphological structure that affects the sports efficiency the most is already known, although the coefficients of participation of individual morphological dimensions in the specification equation indubitably change due to the development of technique and tactics, and modern achievements in a particular sport (Gusic et al., 2017).

Soccer is a sports game played in the open field, and the training is usually based on the continual movement, expressed through endurance, which consists of a series of moderate activities, followed by alternating periods of high intensity, which leads to significant metabolic heat production (Masanovic, 2015). Basketball is considered as one of the acyclic sports games with extremely complex movements and specific and functional char-

Correspondence:

Montenegro B. Masanovic

Gport University of Montenegro, Faculty for Sport and Physical Education, Narodne omladine bb, 81400 Niksic, Montenegro E-mail: bojanma@ac.me 
acteristics; defined as anaerobic-glycotic activity, characterized by a large number of recurring explosive-velocity movement patterns of extremely high intensity (Erčulj et al., 2002; Stojanovic et al., 2016; Masanovic, 2018). It is considered a highly selective sports branch characterized by players with distinct body height and long extremities, while the amount of subcutaneous fat tissue adversely affects the effectiveness of the player and limits his motor and functional potentials (Popovic et al., 2013; Masanovic, Vukotic, Bjelica, \& Popovic, 2018; Popovic, Bjelica, Vukotic, \& Masanovic, 2018; Vukotic, Corluka, Vasiljevic, \& Bubanja, 2018; Vukotic, 2018).

The role of morphological characteristics and body constitution in sport activities is huge. For specific kinesiogical activity type, specific morphology type is necessary for above-average and top result achievement. Also, for above-average and top result achievement, long-term training procces is necessary, with regards of previous selection, genetical basis and social surroundings (Bala, 2000).

The aim of this research is to determine whether there is a difference in anthropometric characteristics between the top soccer and basketball players, and if so, to define the scope of it, and to characterize, as accurately as possible, the morphological characteristics of subjects by measuring their body parts individually.

\section{Methods}

The sample included 40 male subjects divided into two subsamples. The first subsample included 26 subjects, who trained in the senior selection in the Football club "Vojvodina" from Novi Sad, which competed in Super League of Serbia, while the other subsample included 14 subjects who trained in the senior selection in the Basketball club "Vojvodina", which competed in Super League of Serbia as well. Criteria for selection of subjects for the sample were as follows: they have been members of the first team squad for at least one year and that they are in good health.

Anthropometric research technique was used for data col- lection. A total of 20 anthropometric measures were evaluated, that defined the longitudinal and transversal dimensionality of skeleton, body volume and body mass, and subcutaneous adipose tissue: body height, body weight, elbow diameter, wrist diameter, knee diameter, ankle joint diameter, minimum circumference of the upper arm, maximum circumference of the upper arm, minimum circumference of the forearm, maximum circumference of the forearm, minimum circumference of the upper leg, maximum circumference of the upper leg, minimum circumference of the lower leg, maximum circumference of the lower leg, skinfold thickness of the upper arm, skinfold thickness of the forearm, skinfold thickness of the thigh, skinfold thickness of the calf, skinfold thickness of the chest and skinfold thickness of the abdomen.

Anthropometric research was conducted according to IBP standards, while respecting the basic rules and principles related to the selection of parameters, standard conditions and measuring techniques, as well as the standard measuring instruments calibrated before measuring.

The measuring was carried out in the middle of the competitive season. The data obtained in the research were analyzed with the statistical program SPSS 20.0, adapted for use on personal computers. The arithmetic mean, standard deviation and standard errors of the arithmetic mean of the anthropometric characteristics were calculated for respondents who are professional soccer players and professional basketball players, by testing the differences of arithmetic means of independent samples at a significance level of $\mathrm{p}<0.05$. This analysis gave answer to the question whether there is a difference, and the scope of it, between the anthropometric characteristics of the soccer and basketball players, regulars who compete in union divisions.

\section{Results}

This section presents the results of central tendency and dispersion parameters, as well as the results of t-test for indepen-

Table 1. Descriptive Statistics

\begin{tabular}{lcc}
\hline & $\begin{array}{c}\text { Soccer } \mathbf{N}=\mathbf{2 6} \\
\text { AM } \pm \text { SD }\end{array}$ & $\begin{array}{c}\text { Basketball N=14 } \\
\text { AM } \pm \text { SD }\end{array}$ \\
\hline Body height $(\mathrm{cm})$ & $182.11 \pm 6.73$ & $199.50 \pm 7.37$ \\
Bodyweight $(\mathrm{kg})$ & $80.10 \pm 7.13$ & $99.57 \pm 11.61$ \\
Elbow diameter $(\mathrm{mm})$ & $72.71 \pm 3.38$ & $80.95 \pm 3.19$ \\
Wrist diameter $(\mathrm{mm})$ & $58.10 \pm 3.43$ & $65.87 \pm 3.42$ \\
Knee diameter $(\mathrm{mm})$ & $99.33 \pm 3.77$ & $103.58 \pm 7.08$ \\
Ankle joint diameter $(\mathrm{mm})$ & $75.72 \pm 3.22$ & $80.21 \pm 2.45$ \\
Upper arm circumference $(\min )(\mathrm{cm})$ & $30.31 \pm 2.46$ & $33.32 \pm 2.01$ \\
Upper arm circumference $(\max )(\mathrm{cm})$ & $32.15 \pm 1.97$ & $35.32 \pm 2.17$ \\
Lower arm circumference $(\min )(\mathrm{cm})$ & $16.92 \pm 0.89$ & $18.00 \pm 0.85$ \\
Lower arm circumference $(\max )(\mathrm{cm})$ & $16.42 \pm 2.55$ & $28.21 \pm 1.53$ \\
Upper leg circumference $(\min )(\mathrm{cm})$ & $42.27 \pm 2.63$ & $44.14 \pm 2.89$ \\
Upper leg circumference $(\max )(\mathrm{cm})$ & $56.42 \pm 2.66$ & $61.89 \pm 3.18$ \\
Lower leg circumference $(\min )(\mathrm{cm})$ & $24.35 \pm 1.20$ & $25.71 \pm 1.52$ \\
Lower leg circumference $(\max )(\mathrm{cm})$ & $37.85 \pm 1.93$ & $40.93 \pm 2.46$ \\
Upper arm skinfolf $(\mathrm{mm})$ & $4.21 \pm 1.16$ & $4.51 \pm 0.57$ \\
Lower arm skinfold $(\mathrm{mm})$ & $4.84 \pm 0.62$ & $5.33 \pm 0.79$ \\
Thigh skinfold $(\mathrm{mm})$ & $7.33 \pm 2.07$ & $10.96 \pm 3.24$ \\
Calf skinfold $(\mathrm{mm})$ & $6.14 \pm 1.53$ & $8.06 \pm 2.46$ \\
Chest skinfold $(\mathrm{mm})$ & $6.47 \pm 1.35$ & $8.38 \pm 3.16$ \\
Abdomen skinfold $(\mathrm{mm})$ & $6.34 \pm 1.38$ & $7.69 \pm 2.51$ \\
\hline
\end{tabular}

Legend: $\mathrm{N}$ - number of Subjects, AM - arithmetic mean, S - standard deviation 
dent samples, classified into tables. Observing the results, the differences of the central tendency and dispersion parameters can be immediately noticed between the top soccer and top basketball players when it comes to the parameters of longitudinal and transversal skeletal dimensionality, body volume and body mass. Those differences are not as visible and emphasized in the parameters for the evaluation of subcutaneous adipose tissue. Basketball players have higher values when it comes to all the variables (Table 1).

On the basis of the results presented it was determined that the subsamples are significantly different in 19 out of 20 an- thropometric characteristics (level of significance $\mathrm{p}<0.05$ ). Basketball players show significantly higher values in 19 variables: body height, body weight, elbow diameter, wrist diameter, knee diameter, ankle joint diameter, upper arm circumference (min), upper arm circumference $(\max )$, lower arm circumference (min), lower arm circumference (max), upper leg circumference (min), upper leg circumference $(\max )$, lower leg circumference (min), lower leg circumference ( $\max$ ), lower arm skinfold, thigh skinfold, calf skinfold, chest skinfold and abdomen skinfold. In one anthropometric characteristic, upper arm skinfold, basketball players do not have significantly higher values (Table 2).

Table 2. Independent Samples t-test

\begin{tabular}{lcccccccc}
\hline & $\mathbf{F}$ & $\mathbf{t}$ & $\mathbf{d f}$ & $\mathbf{P}$ & $\mathbf{M D}$ & SED & Min & Max \\
\hline Body height & .09 & -7.54 & 38 & .000 & -17.39 & 2.3 & -22.05 & -12.72 \\
Bodyweight & 5.23 & -6.59 & 38 & .000 & -19.47 & 2.95 & -25.46 & -13.50 \\
Elbow diameter & .17 & -7.48 & 38 & .000 & -8.22 & 1.09 & -10.45 & -5.92 \\
Wrist diameter & .01 & -6.84 & 38 & .000 & -7.77 & 1.14 & -10.07 & -5.48 \\
Knee diameter & 5.08 & -2.49 & 38 & .017 & -4.25 & 1.70 & -7.70 & -.80 \\
Ankle joint diameter & 1.97 & -4.54 & 38 & .000 & -4.49 & .99 & -6.49 & -2.48 \\
Upper arm circumference (min) & .15 & -3.92 & 38 & .000 & -3.01 & .77 & -4.56 & -1.45 \\
Upper arm circumference (max) & .02 & -4.68 & 38 & .000 & -3.16 & .67 & -4.54 & -1.80 \\
Lower arm circumference (min) & .00 & -3.69 & 38 & .001 & -1.08 & .29 & -1.66 & -.48 \\
Lower arm circumference (max) & .22 & -2.39 & 38 & .021 & -1.79 & .75 & -3.30 & -.28 \\
Upper leg circumference (min) & .27 & -3.18 & 38 & .003 & -2.87 & .90 & -4.69 & -1.04 \\
Upper leg circumference (max) & .78 & -5.79 & 38 & .000 & -5.47 & .94 & -7.38 & -3.55 \\
Lower leg circumference (min) & 1.29 & -3.14 & 38 & .003 & -1.37 & .43 & -2.25 & -.49 \\
Lower leg circumference (max) & 1.06 & -4.36 & 38 & .000 & -3.08 & .70 & -4.51 & -1.65 \\
Upper arm skinfolf & 1.05 & -.91 & 38 & .370 & -.29 & .33 & -.97 & .37 \\
Lower arm skinfold & .74 & -2.18 & 38 & .035 & -.49 & .23 & -.951 & -.03 \\
Thigh skinfold & 1.81 & -4.34 & 38 & .000 & -3.63 & .84 & -5.33 & -1.94 \\
Calf skinfold & 4.83 & -3.05 & 38 & .004 & -1.92 & .63 & -3.19 & -.64 \\
Chest skinfold & 2.44 & -2.69 & 38 & .011 & -1.91 & .71 & -3.35 & -.47 \\
Abdomen skinfold & 3.96 & -2.19 & 38 & .034 & -1.34 & .61 & -2.58 & -.10 \\
\hline
\end{tabular}

Legend: $F$-value of Levene's test of equality of variances, $t$-value of $t$-test, df-number of degreeseof freedom, $p$-significance of two-tailed testing of arithmetic mean difference, MD-arithmetic mean difference, SED-standard error of diffeence, Min-the level of lower difference interval, Max-level of upper difference interval

\section{Discussion}

On the basis of the data obtained in this study, it was found that there are significant differences in certain anthropometric characteristics between soccer players and basketball players in the highest rank of competition. Results relating to measures of the skeleton longitudinality and transversal, as well as body volume and body mass showed significantly higher values for basketball players. Subcutaneous adipose tissue showed significantly higher values for basketball players in 5 out of 6 variables (lower arm skinfold, thigh skinfold, calf skinfold, chest skinfold, abdomen skinfold). The fifth variable, upper arm skinfolf, was also of higher value for basketball players, though very slightly.

Being a professional athlete requires a high level of preparation which, in addition to motor and functional abilities, must be supported by morphological characteristics that should correspond, through the perfect harmony, based on sport structure, to the rank of the competition and the spe- cifics of the player position, which differ within almost every sport branch.

The aim of this research was to determine whether there is a difference, and the scope of it, in anthropometric characteristics between the top soccer and basketball players, and to characterize, as acurately as possible, the morphological characteristics of subjects by measuring the individual body parts.

Considering the movement patterns in basketball, greater body height and body mass, bigger diameters of all joints, and higher values of extremities' circumferences, are expected primarily for the reason that basketball is a sport in which body height gives advantage in defence and attack because taller players have the ability to easily reach the basket, and block the opponent's attach respectively (Popovic et al., 2014; Vukasevic, Vukotic, \& Masanovic, 2018; Vukašević, Spaic, \& Masanovic, 2018). The next reason is that the average body height of basketball players has increased significantly in the last 20 years, and the reasons for this can be found in the sec- 
ular trend (Sedeaud et al., 2014) and good selection process. Also, body mass of basketball players is noticeably bigger, so the contemporary basketball player reminds of a colossus under the hoop that can be thrown out of the racket solely by using even greater force. In the end, the use of supplements in nutrition, and sometimes even unauthorized remedies that help accelerate muscle growth is increasingly present as well (Hasegawa et al., 2014).

Movement patterns in soccer are the reason for lower subcutaneous adipose tissue values for soccer players because in research, soccer is recognized as an aerobic sport in which activity lasts longer and running distance is greater (Popovic et al., 2013; Masanovic, Popovic, \& Bjelica, 2018; Mašanović, Popović, \& Molnar 2009; Popovic et al., 2009; Popovic, Molnar, \& Masanovic, 2010; Popovic et al., 2010; Gardasevic, Bjelica, \& Popovic, 2015; Gardasevic \& Bjelica 2014). On the other hand, basketball is played on a smaller pitch, the running distance during the match is smaller which justifies somewhat higher value of the thickness of the skin folds. However, these are the variables in which the difference is the smallest, seen mostly in the upper arm skinfolf variables (only slightly higher than for soccer players), lower arm skinfold and abdomen skinfold. The reason for the slight difference between the skinfold thicknesses of the upper extremities can be found in the fact that basketball players use both upper and lower extremities during the game, which is not the case in soccer.

Morphological characteristics of topclass soccer and basketball players appear to be of great interest for some authors (Saether, 2017; Madic et al. 2018; Gjonbalaj et al., 2018; Pojskic et al., 2014; Gajardo-Burgos et al., 2018) with the interest of finding the best morphology somatotype for particular sports, competition levels and player positions as well. Comparison of anthropometrics should support coaches with better understanding of specific demands of certain sport, where particular morphology profile of athlete, combined with motor and functional abilities, should express its full potential (Gusic et al., 2017).

\section{Acknowledgements}

There are no acknowledgements.

\section{Conflict of Interest}

The authors declare that there are no conflicts of interest.

Received: 1 May 2018 | Accepted: 29 June 2018 | Published: 29 October 2018

\section{References}

Bala, G. (2000). Dependence of the morphological dimension definition on the number of manifest anthropometric variables. Journal of the Anthropological Society of Yugoslavia, 35, 95-102.

Bjelica, D. (2002). Opšti pojmovi sportskog treninga: (skraćena verzija). Podgorica: Crnogorska sportska akademija.

Bjelica, D. (2013). Teorija sportskog treninga. Podgorica: Univerzitet Crne Gore.

Bjelica, D., i Fratrić, F. (2011). Sportski trening: teorija, metodika i dijagnostika Nikšić: Fakultet za sport i fizičko vaspitanje.

Bourgois, J., Claessens, A., Vrijens, J., Philippaerts, R., Van Renterhem, B., Thomis, M., Jansses, M., Loos, R., \& Lefevre, J. (2000). Anthropometric characteristics of elite male junior rowers. British Journal of Sport Medicine, 34(3), 213-6.

Erčulj, F., Dežman, B., Vučkovič, G.\& Milič, M. (2002). Functional abilities of elite female basketball players in different playing positions. Acta Kinesiologia Universitatis Tartuensis,7,75-80.

Gajardo-Burgos, R., Barria-Vargas, C., Flandrez-Valderrama, J., Avendano-Chipon, R., Barria-Pailaqilen, R.M., \& Monrroy-Uarac, M. (2018). Perfil Antropométrico de Basquetbolistas Sub-14 Chilenos. Int. J. Morphol., 36(3),943-7.
Gardasevic, J., \& Bjelica, D. (2014). The effects of the training in the preparation period on the dribbling speed with fifteen years old football players. Sport Mont, 12(40-41-42), 160-6.

Gardasevic, J., Bjelica, D., \& Popovic, S. (2015). The effects of the training in the preparation period on the agility transformation with cadet level football players. Sport Mont, 13(43-44-45), 355-60.

Gjonbalaj, M., Georgiev, G., \& Bjelica, D. (2018). Differences in Anthropometric Characteristics, Somatotype Components, and Functional Abilities Among Young Elite Kosovo Soccer Players Based on Team Position. Int. J. Morphol., 36(1),41-7.

Gusić, M., Popović, S., Molnar, S., Mašanović, B., \& Radaković, M. (2017). Sport-Specific Morphology Profile: Differences in Anthropometric Characteristics among Elite Soccer and Handball Players. Sport Mont, 15(1), 3-6.

Hasegawa, Y., Mekata, Y., Sunami, A., Yokoyama, Y., Yoshizaki, T., Hagiwara, M., Yanagisawa, K., Usuda, M., Masuda, Y., Kawano, Y. (2014). Effect of Egg White Protein Supplementation Prior to Acute Resistance Training on Muscle Damage Indices in Untrained Japanese Men. Montenegrin Journal of Sports Science and Medicine, 3(2), 5-12.

Madic, D., Andrasic, S., Gusic, M., Molnar, S., Radanovic, D., \& Trajkovic, N. (2018). Seasonal Body Composition Variations in Adolescent Soccer Players. Int. J. Morphol., 36(3),877-80.

Masanovic, B. (2015). Anthropological indicators of the proprioceptive training success with football players and students aged 15-16 years. Unpublished Doctoral Dissertation. Novi Sad: University of Novi Sad.

Masanovic, B. (2018). Comparative study of anthropometric measurement and body composition between junior basketball and volleyball players from Serbian national league. Sport Mont, 16(3), 19-24. doi: 10.26773/smj.181004

Masanovic, B., \& Vukasevic, V. (2009). Differences of anthropometrical status on basketball and handball players in junior stature. Sport Mont, 6(1819-20), 576-82.

Mašanović, B., Popović, S. \& Molnar, S. (2009). The differences in some anthropometric characteristics of elite football and basketball players. In Book of Abstracts XLVIII Congress of Anthropological Society of Serbia (87). Prolom Banja: Antrpological Society of Serbia.

Masanovic, B., Popovic, S., \& Bjelica, D. (2018). Comparative Study of Anthropometric Measurement and Body Composition Between Junior Soccer and Volleyball Players From National League. In Book of Abstracts 15th International Scientific Conference on Transformation Process in Sport "Sport Performance" (58), Podgorica: Montenegrin Sports Academy.

Masanovic, B., Vukotic, M., Bjelica, D., \& Popovic, S. (2018). Describing Physical Activity Profile of Older Montenegrin Males Using the International Physical Activity Questionnaire (IPAQ). In Book of Abstracts 15th International Scientific Conference on Transformation Process in Sport "Sport Performance" (61), Podgorica: Montenegrin Sports Academy.

Pojskic, H., Serapovic, V., Muratovic, M., \& Uzicanin, E. (2014). Morphological Differences of Elite Bosnian Basketball Players According to Team Position. Int. J. Morphol., 32(2),690-4.

Popovic, S., Akpinar, S., Jaksic, D., Matic, R., \& Bjelica, D. (2013). Comparative Study of Anthropometric Measurement and Body Composition between Elite Soccer and Basketball Players. International Journal of Morphology, 31(2), 461-7.

Popovic, S., Akpinar, S., Jaksic, D., Matic, R., \& Bjelica, D. (2013). Comparative Study of Anthropometric Measurement and Body Composition between Elite Soccer and Basketball Players. International Journal of Morphology, 31(2),461-7.

Popović, S., Bjelica, D., Jakšić, D., \& Hadžić, R. (2014). Comparative Study of Anthropometric Measurement and Body Composition between Elite Soccer and Volleyball Players. Int. J. Morphol., 32(1),267-74.

Popovic, S., Bjelica, D., Vukotic, M., \& Masanovic, B. (2018). Describing Physical Activity Profile of Older Montenegrin Females Using the International Physical Activity Questionnaire (IPAQ). In Book of Abstracts 15th International Scientific Conference on Transformation Process in Sport "Sport Performance" (60-61), Podgorica: Montenegrin Sports Academy.

Popovic, S., Masanovic, B., Molnar, S., \& Smajic, M. (2009). Determining Body Composition of Top Level Athletes. Teme, 33(4), 1534-49.

Popovic, S., Molnar, S., \& Masanovic, B. (2010). Differences of some anthropometrical characteristics on young football players and boys who don't do any sport. Journal of Antrpological Society of Serbia, 45, 273-9.

Popovic, S., Smajic, M., Joksimovic, A., \& Masanovic, B. (2010). The differences in body composition between football players of different rank competitions. Sport Mont, 8(23-24), 362-7.

Sæther, S. A. (2017). Characteristics of professional and non-professional football players - an eight-year follow-up of three age cohorts. Montenegrin Journal of Sports Science and Medicine, 6(2), 13-8.

Sedeaud, A., Marc, A., Schipman, J., Schaal, K., Danial, M., Guillaume, M., Berthelot, G., \& Toussaint, J.F. (2014). Secular trend: morphology and 
performance. Journal of sports sciences, 32(12):1146-54

Stojanovic, M., Calleja-Gonzalez, J., Mikic, M., Madic, D., Drid, P., Vučković, I, \& Ostojić, S. (2016). Accuracy and Criterion-Related Validity of the 20-M Shuttle Run Test in Well-Trained Young Basketball Players. Montenegrin Journal of Sports Science and Medicine, 5(2), 5-10.

Vukasevic, V., Spaic, S., \& Masanovic, B. (2018). Comparative study of anthro pometric measurement and body composition between the basketball player first and second league in Montenegro. Journal of Anthropology of Sport and Physical Education, 2(3), 61-65. doi: 10.26773/jaspe.180711

Vukasevic, V., Vukotic, M., \& Masanovic, B. (2018). Comparative study of morphological characteristics and body composition between basketbal players from second leagues in Montenegro and Serbia. Journal of Anthropology of Sport and Physical Education, 2(3), 21-25. doi: 10.26773/ jaspe. 180704

Vukotic, M. (2018). Comparative analysis of antropmtric indicators of sportisis of different soprts guidance. In Book of Abstracts 15th International Scientific Conference on Transformation Process in Sport "Sport Performance" (75-76), Podgorica: Montenegrin Sports Academy.

Vukotić, M., Čorluka, M., Vasiljević, I., \& Bubanja, M. (2018). Differences in the Morphological Characteristics and Body Composition of Handball Players WHC Levalea in Montenegro and WHC Grude in Bosnia and Herzegovina. J. Anthropopogy Sport and Physical Education, 2(2),49-53 